al-Ihkam: Jurnal Hukum dan Pranata Sosial, 16 (1), 2021: 161-179

ISSN: 1907-591X, E-ISSN: 2442-3084

DOI: http://doi.org/10.19105/al-ihkam.v16i1.3861

\title{
Binsabin dan Tongngebban as Madurese Local Wisdom: An Anthropology of Islamic Law Analyses
}

\author{
Suhaimi \\ Fakultas Hukum Universitas Madura Pamekasan \\ Jln. Raya Panglegur KM. 03 Pamekasan \\ Email: suhaimi.dorez@gmail.com \\ Agustri Purwandi \\ Fakultas Hukum Universitas Madura Pamekasan \\ Jln. Raya Panglegur KM. 03 Pamekasan \\ Email: a3purwandi@yahoo.com
Akhmad Farid Mawardi Sufyan
Sharia Faculty Institut Agama Islam Negeri (IAIN) Madura, Jl. Panglegur
KM. 4 Pamekasan
Email: faridmawardi@iainmadura.ac.id

Article history: Received: August 07, 2020, Accepted: May 30, 2021, Published: June 27, 2021

\begin{abstract}
:
There is a unique tradition in the Madurese community of East Java, namely Binsabin and Tongngebban. Both are the absolute requirements for a valid engagement. It means that the engagement is not totally legal without the two things. In the perspective of Islamic law, this is permitted, but from an anthropological perspective, found that there is a social inheritance that is imposed on social bonds, the rules of marriage law and ceremonies in the marriage process. In line with that, this paper wants to describe a local wisdom in a proportional framework, not only seeing society legally, but also society must be seen as a culture (anthropology). This paper is collected from data interviews with two different types of community groups. The results of the study show that first, from an anthropological perspective; the binsabin and tongngebban traditions express the fulfillment of individual psycho-biological needs and maintain the continuity of life of social groups. Anthropology also shows strong the Madurese community is in upholding this tradition from generation to generation even though times round and round. Second, in the perspective of Islamic law, this tradition seeks to build

Author correspondence email: suhaimi.dorez@gmail.com Available online at: http:/ / ejournal.iainmadura.ac.id/index.php/alihkam/ Copyright (c) 2021 by al-ihkam. All Right Reserved


three things, first building a strong agreement between fellow Muslim families, second establishing friendship so as to create a strong emotional bond, third sharing the joy that shown by giving gifts or goods so as to increase the strength of brotherly bonds by religious way (engagement).

Keywords:

Binsabin; Tongngebban; Anthropology, Islamic Law

\begin{abstract}
Abstrak:
Terdapat tradisi yang unik di masyarakat Madura Jawa Timur yakni Binsabin dan Tongngebban. Dua hal tersebut menjadi syarat mutlak sahnya suatu pertunangan. Artinya bahwa pertunangan tidak dianggap sah secara adat apabila tidak disertai dengan kedua hal di atas. Dalam perspektif hukum Islam memang hal ini tidak bertentangan, akan tetapi dalam kacamata antropologi ditemukan bahwasanya terdapat warisan sosial yang dipaksakan dalam ikatan sosial, aturan-aturan hukum perkawinan dan upacara-upacara dalam proses perkawinan tersebut. Sejalan dengan itu tulisan ini ingin memetakan kerarifan lokal dalam kerangka yang proporsional yakni bukan hanya melihat masyarakat secara hukum saja akan tetapi masyarakat harus dilihat sebagai sebuah budaya (antropologi). Tulisan ini dikumpulkan dari data hasil wawancara pada dua kelompok masyarakat yang bertipe berbeda. Hasil penelitian menunjukkan bahwasanya pertama, dalam kacamata antropologi, tradisi binsabin dan tongngebban mengekspresikan Pemenuhan kebutuhan psiko-biologis individu dan menjaga kesinambungan hidup kelompok social. Antropologi juga melihat bagaimana kuatnya masyarakat Madura dalam memegang teguh tradisi ini secara turun temurun meskipun zaman sudah berubah modern seperti saat ini. Kedua, dalam perspekktif hukum Islam tradisi ini berupaya membangun tiga hal yakni membangun kesepakatan yang kuat antar sesama keluarga muslim, kedua menjalin silaturrahim sehingga tercipta ikatan emosional yang kokoh, ketiga saling berbagi kegembiraan yang ditunjukkan dengan pemberian hadiah atau barang-barang sehingga menambah kuat ikatan persaudaraan dengan cara yang religius (pertunangan).
\end{abstract}

Kata Kunci:

Binsabin; Tongngebban; Antropologi, Hukum Islam 


\section{Introduction}

Discussing about Madura Island can open the minds of researchers to investigate further about its heterogeneous sociocultural condition. It has a lot of uniqueness, especially regarding the local culture characterized by creativity, taste, and intention of the Madurese community. All of these are often carried out by the majority of the community as part of customary law, which has been passed down or practiced. If it is not maintained, then the lawfulness of their belief is still questionable. Various issues of custom and tradition that develop in Madurese community, for example in civil matters, include marriage, inheritance, waqaf (donation), and other problems, based on their own uniqueness.

In the case of marriage, there is a compulsory momentum before the marriage takes place, which is called engagement. According to the teachings of Islam, this momentum is highly recommended for the benefit of the marriage. However, according to the perspective of Madurese custom, following traditions that are usually carried out by the ancestors of the Madurese community becomes an obligation. Traditions that must be carried out before marriage are called Binsabin and Tongngebban. If these two things are not done, then the engagement is considered unlawful in the view of Madura customary law, and it may be possible to cancel the engagement so that the desired marriage cannot take place.

Engagement is a bond between a man and a woman by making a marriage agreement in accordance with customary provisions that apply in the community. Engagement can also be called a period of contemplation, a moment of thinking for the groom and bride before getting married. During this period, they mutually introspect about the existence of each other and their families, as well as their strengths and weaknesses. After they are sure, and there are no obstacles either in Islamic or customary law, the next step is to continue to the level of marriage.

The steps taken in Madurese tradition of engagement are, first, a man proposes to a woman he likes to his guardian or family. After the proposal is accepted, the second step is conducting binsabin tradition. Binsabin is the tradition when some family members of the man, as the representatives, come to the woman's family to bind the 
woman who is being proposed legally so that other men cannot propose to her. Binding this woman in Madurese terms is called "letaleh or nale'eh. ${ }^{1}$ In binsabin, the man's family must bring something as a sign of lawful bond in the form of several pieces of betel leaf, areca nut, a bunch of bananas, and a typical Madura cake in the form of wajik, tettel, and other needed cakes. The third step is tongngebban carried out by the woman's family to come to the man's family in return for strengthening the engagement that has been carried out. The process is almost the same as binsabin, but the difference is the woman's family does not need to bring betel leaf and areca nut. If the three processions have been carried out, then the engagement is considered lawful under the customary law. ${ }^{2}$

Maintaining the traditions of Madurese community in order to keep developing and to become a role model for the next generation, the authors conduct a research that aims to find out and to analyze further the good traditions in Madura. There are many unique things that become the personality of the Madurese community, which are not possessed by other local communities, especially traditions with positive impacts, which can then become traditions from generation to generation.

Based on the description that has been described earlier, it is very necessary to conduct an in-depth review of this tradition from the perspective of Islamic law in order to prevent practices that deviate from Islamic teachings. Thus, the problem formulations of this study are (1) How is the tradition of Binsabin and Tongngebban in Madurese engagement beyond anthropology perspective? (2) How is the tradition of Binsabin and Tongngebban from the perspective of Islamic law?

\section{Method}

In this study, the researchers used a qualitative approach. A qualitative approach is a research procedure that obtains descriptive data in the form of written words or writings from people or observed behavior. ${ }^{3}$ The type of research is an empirical study involving the

\footnotetext{
1 Urip Santoso, "Local Public Figure" Direct Interview at 30 of June 2020.

2 Urip Santoso Direct Interview at 30 of June 2020.

${ }^{3}$ Lexy J. Moleong, Metode Penelitian Kualitatif (Bandung: Rosda Karya, 2000), 3.
} 
community, especially the Madurese community. This research was directly conducted to the community by digging information in depth through informants, either directly or indirectly involved in the traditional engagement practices.

\section{Discussion and result}

Binsabin Tradition and Tongngebban in Madurese Traditional Engagement

Engagement is the first step that must be done before the marriage takes place. Besides being a religious doctrine, it is also a common practice in local customs. ${ }^{4}$ In general, engagement is only an initial bond so that a man and a woman who are engaged are not allowed to have someone else because there is an agreement between the two sides of the family to enter into an engagement bond. However, the practices and procedures are not determined by sharia, all of which are returned to local customs or traditions (local wisdom).

Regarding Madurese traditional engagement, there are a number of traditions that must be carried out by parties wishing to do the engagement. If the series of tradition is not implemented, then it is considered to have violated the applicable customary provisions. Thus, they get moral sanctions in the form of being a topic of a gossip in the community, being ostracized, and cancellation of the engagement because it is considered unlawful in the perspective of customary law.

Honestly this is part of the procession that has been guided by religion. Anthropologically it is described as the relation of cultural customs with Islam. This phenomenon is seen as not mistaken by Islam, ic law, so that it continues to apply sustainably in society. 5 This kind of anthropological phenomenon is natural, as a form of a way of living together as fellow members of society. In the Nusantara tradition, binsabin and Tongngebban are similar to seserahan (giving

\footnotetext{
${ }^{4}$ Umi Supraptiningsih and Khoirul Bariyyah, "Marriage Settlement among Minority Moslem by Datok Imam Masjid in South Thailand," AL-IHKAM: Jurnal Hukum $\mathcal{E}$ Pranata Sosial 14 (2019): 223.

${ }^{5}$ H. Lebba Kadorre Pongsibone, Islam Dan Budaya Lokal; Kajian Antropologi Agama, ed. M. Fatih Mansur, Kaukaba Dipantara, I (Yogyakarta: Kaukaba Dipantara, 1967), 16.
} 
some goods in wedding), except that they are not given during the marriage ceremony, but are given at the engagement ceremony. 6

In the Madurese customary provisions, this engagement is a custom, and it can even be said to be compulsory in the provisions of customary law. ${ }^{7}$ Marriage that does not begin with engagement ${ }^{8}$ will have a social impact. First, it becomes a public issue because the marriage is carried out without prior introduction. It is as if the public were shocked and caused big questions. Second, it raises slander in the form of public suspicion like something negative has happened so the marriage is carried out as soon as possible. Third, it may cause damage to the marital relationship because they do not really know each other ( $\left.t a^{\prime} a r u f\right)$. Thus, it causes disappointment when there is something disgrace that is not previously known by each other.

The Madurese traditional engagement begins with a man's request for a woman to have a marriage agreement (nikah) with a mutually agreed time. This process in the language of figh is called propose (khitbah). ${ }^{9}$ Before carrying out this process, the man's family seeks information regarding the situation of the woman and her family to be proposed. This search for information in the Madurese traditional term is called Nginangen or Nyare Angin. ${ }^{10}$ The aim is to find valid and objective data on the condition of the woma related to her face, economic condition, lineage, and religion. These four things are the main orientation in finding a partner so that later, in household life, they reach the sakinah, mawaddah and warahmah family under the blessings of Allah SWT.

Nyareh Angin in engagement customs is actually a very positive thing to do as the first step before visiting the woman's family, as an act of precaution so as not to make a wrong move ${ }^{11}$.

${ }^{6}$ J. Van Baal, Sejarah Dan Pertumbuhan Teori Antropologi Budaya (Hingga Dekade 1970), I (Jakarta: PT. Gramedia, 1987), 20.

${ }^{7}$ Tolib Setiady, Intisari Hukum Adat Indonesia (Bandung: Alfabeta, 2009), 8. 8 Suhaimi, "Praktik Khitbah Di Madura Perspektif Hukum Islam Dan Hukum Adat," Al Ihkam: Jurnal Hukum Dan Pranata Sosial IX, no. 2 (2014): 286.

9 Ahmad Warson Munawwir, Kamus Al-Munawwir (Surabaya: Pustaka Progressif, 1997), 349.

${ }^{10}$ H. Soeprijadi, “Local Public Figure” Direct Interview on 04 of August 2020.

${ }^{11}$ In the Madurese language, it is said to be ma'le ta 'salatengka because the matter of tengka is considered the main thing by the Madurese as a form of self-respect that cannot be underestimated. Thus, in this matter, there is a slogan attached to the 
Moreover, it also keeps the possibility that unwanted things will not occur, namely the woman does not accept the proposal. By doing nginagin, there are already rumors that the possibility of the proposal will be accepted or not. Therefore, if there is news that the marriage will be accepted by the woman, then the next step will be taken, namely directly proposing. However, if it is certain that the proposal will not be accepted, the steps to propose will never be taken. The refusal of the marriage by the woman will cause social jealousy, shame, feelings of humiliation, and so on.

After nginangin is carried out, the next step is to propose (khitbah) from the man's family to the woman's family. It means that the man comes to the woman to ask for engagement. This is called "nyabe" oca" in Madurese. ${ }^{12}$

There are two ways to propose an engagement request. First, the request is made by the man's parents. One of the parents or both (the man's mother and father) visit the woman's parents, then explaining their good intention. Second, the proposal is carried out through a delegation or representative. People who are sent are usually elders, leaders, community leaders, and religious figures who are considered capable of carrying out their responsibilities in proposing. This second method is commonly used by the Madurese community. It is proven that the Madurese community really values their elders, community leaders, and scholars (ustadz and kiai).

The next step after accepting the proposal is Binsabin. Previously, there was an agreement about what will be done within the stipulated time between the two families ${ }^{13}$. The man's family will visit the woman's family to do the official customary engagement. This procession is called Binsabin in the Madurese engagement custom. In the Madurese customary provisions, Binsabin is

Madurese community with the emphatic language of "lebbi bagus pote tolang etembang pote matah" (better white bones than the whites of the eyes). It implied that it is better to die than to have honor be humiliated.

12 H. Soeprijadi, "Local Public Figure."

13 The timing of binsabin has been determined by the man's family when proposing or asking to be engaged, delivered by the man's family delegate that is then approved by the woman's family. The time specified is usually not far from the time of proposal. It may be at least three days, one week, and a maximum of five days after the proposal is declared accepted. 
compulsory to determine whether an engagement from a traditional perspective is lawful, and it becomes a sign that the woman is officially engaged to the man, so other men are not allowed to propose to her. The woman already has a cage, in the Madurese proverb, it is stated as "Ibarat mano'dhalem Korong" (like a bird in a cage). This means that the woman already has a man.

Binsabin is a series of processions in the engagement custom of the Madurese community carried out by the man's family to do official engagement so that it is lawful according to customary provisions. Some Madurese people mention Binsabin in another term, namely mogel. ${ }^{14}$ The term mogel in Indonesian is defined as binding, grasping, fencing (nale'e pagar) so that the woman is not free from the bond and is not allowed to accept someone else's proposal before being released from her fiance.

The things that need to be prepared in the Binsabin procession in the Madurese engagement are first, in the beginning, at least three days before, the man must invite some people in his relatives to participate in the binsabin event according to the predetermined time. They are from the closest family in the family order. If there is not, then they can be from a rather distant family; the most important thing is that they are still within the family circle. In addition, some of the neighbors who are closest to the house of the man are invited (sohibu al-hajat). The intention is that some of the neighbors should know that their son is being engaged ${ }^{15}$. The number of people who are asked to participate must be the same as in the agreement; should not exceed or reduce it since it is related to the preparation of meal and accommodation provided by the host from the woman's family.

Second, the next step is preparing everything in the form of trinkets that will be brought to the house of the woman's family (prospective female fiancée). The items that are needed to be brought and are the main things that must be present are sere penang (betel leaf and young areca nut), bananas, bajik cake, and tettel. ${ }^{16}$ Betel leaves,

14 Urip Santoso, “Local Public Figure” Direct Interview on 30 July 2020.

15In Madurese terms, it is called makaber, providing information to close neighbors about the status of their son who wants to get engaged. Meanwhile, in Arabic it is called I'lam al-Khitbah.

${ }^{16}$ The bajik and tettel cakes are ancient Madurese cakes made when there is a celebration or event in the form of; engagement, wedding, or important moments that 
young areca nuts, and bananas are placed in a vessel called tenong, which is made of brass.

The items to be brought that have been determined during Binsabin are not just ordinary stuff. There is a deep philosophical meaning in the form of betel leaves, young areca nuts, and bananas. The betel leaf shows that the leaves have many benefits to be used as a potent potion in observing various diseases. Besides, the most important thing is that it can be used as a potion for a woman to always look beautiful and always keep the smell of her virginity when she becomes a wife.

Young areca nut (penang ngodah) indicates the suitor is a young virgin man (lancheng kepaceng), and the areca nut can be used as a potion that will provide the basic needs for his future wife. Young areca nut is known to be very effective in providing stamina for men. Meanwhile, the number of banana brought is one joint (sakejang). The philosophical meaning in engagement customs is that the bananas brought includes raw bananas, which indicates that the engagement period will still be long. If the banana is a little ripe, it shows the engagement period will be short and soon it will enter the momentum of the marriage. If the bananas are very ripe, it indicates that the time for the marriage that the man wants is very close. Therefore, whatever is brought in the Binsabin program implies certain meanings and signs according to the tradition of the Madurese elders. Thus, it is necessary to think about the items that will be brought in the procession so that there is no misunderstanding between the two parties, which causes the cancellation of the engagement.

Other items that are brought for the Binsabin event, besides the five things mentioned above, are various kinds of pastries. The type depends on the person who brought it. Each person in the group of the man's family will bring one type of cake. It is required that each person brings a different type of cake. Thus, before the Binsabin day,

need the cakes. Bajik cake is made from sticky rice by processing them in such a way, given sugar and made colorful. After it is cooked, the cake is placed in a place in the form of a tray that is rectangular or circular in shape. The most important thing is that the size is not too big so it is practically easy to carry. Meanwhile, the tettel cake is also made from glutinous rice flour, which is processed in the same way, but it is not given sugar and is not made colorful. This means that the color remains white as the color of the flour. 
there must be coordination regarding the cakes they bring so that there is no similarity. The cake carriers are usually women, while men do not need to bring anything.

Some Madurese people add a kind of jajan praben, ${ }^{17}$ which is a kind of tart decorated in such a way that it looks good and fun. Usually the names of the engaged parties are written at the top of the cake. With such writing, it is hoped that they will become an eternal spouse without any problems in the household in the future.

The items brought at the time of Binsabin are actually as a sign of compassion, which in Madurese is called tandha pangestoh. The two families stay in touch with each other, and share happiness by giving a kind of gift so that the emotional bond between the two families is getting closer. Gifts may leave memories in the heart of others, and they will never be forgotten. Therefore, from this Binsabin event, it is expected that the two future partners will increasingly form a sincere love with the pleasure of Allah Almighty, and both sides of the family will increasingly unite into a big family that supports each other.

Third, after everything has been prepared, the man's family-in group-will go to the woman's family home, led by one person acting as the group leader. The person also becomes the family representative to deliver the intention of the man's arrival, namely nale'e pagar, that is, to bind the future woman in an official engagement bond according to the customary law.

The format of the program commonly used in the Binsabin event includes (1) opening the ceremony by the recitation of basmalah (bismillah) or al-Qur'an Surah al-Fatihah; (2) presenting the intent and purpose of the arrival of the man's family presented by the head of the group, and then continued by presenting the remarks or answers presented by the representatives of the woman's family; (3) closing the ceremony or prayer; and (4) social section.

After the Binsabin event has been carried out, the next step in the Madurese Engagement is Tongngebban. ${ }^{18}$ Tongngebban is a

\footnotetext{
17 It is named kuepraben (virgin cake) because the proposed woman is a virgin woman. The cake is only as an addition for those who are economically able since the price is quite expensive.

18 Tongngebban is derived from the word tongngebor nongngep; if it is illustrated in a person, it is a prone position, meaning here is to close or repay the kindness in the form of silaturrahim (visit) that has been done previously.
} 
gathering event carried out by the woman's family to respond to what has been done previously by the man's family. It can be said that Tongngebban is the reply from Binsabin. Binsabin is carried out by the man, while Tongngebban is carried out by the woman. This means for a balance between the two families.

In the customary provisions, the Tongngebban event should be carried out by the woman's family. The implementation is a minimum of three days, or a maximum of one week from the Binsabin event. Regarding the preparations that should be done, generally it is the same as the preparations made during the Binsabin. However, the difference is related to the goods, namely the absence of lemongrass, areca nuts, and bananas. Meanwhile, there are no certain provisions about the types of cakes that should be brought since it depends on those who bring it.

Even though the procedure is the same as the technical event of Binsabin, several important things should be considered in the Tongngebban event. First, (1) it needs to pay attention to the number of people participating in the event, which must be the same as the Binsabin event conducted by the man's family; for example, if there are 20 people take part in the Binsabin event, then there should be 20 people as well that participate in the Tongngebban event. Second, (2) the goods that should be carried are not required to be of the same type as before, however, they can be in the same value; most importantly, there is a kind of tandha pangestoh or a gift to streng then the brotherhood that can unite the two families. While the format of the Tongngebban event is exactly the same as the Binsabin event, including: opening, remarks, and closing or prayer, then continued with the social section.

\section{Binsabin and Tongngebban in Madurese Customary Engagement Based on Anthropology Perspective}

Binsabin and Tongngebban in the context of anthropology are studies in the structural-functional matters. This is examining community culture through patterns of functioning relationships between individuals, between groups, or between social institutions within a society, at a certain period of time represented by the culture 
of society.19 The concept of structure and function was introduced by Radcliffe Brown. According to Radcliffe Brown, structure gave birth to the term model of society. This model is very firmly rooted in a society and will be difficult to disappear even though the times and people have changed. Binsabin and tongngebban in the context of the structure and function of the Madurese are a representation of the strong tradition that has been rooted in society and its people so that the term appears that binsabin and tongngebban are "obligatory"20 in an engagement.

According to Radcliffe Brown, what is interesting in a cultural structure is not how to see humans as individuals, but how to see their social status. Social status in question is social status at the level of thought. For example, in a traditional society, the way of thinking, behavior and habits will be very different from that of modern society. In this context, the Madurese community seems to be a society that highly respects customs, traditions, even though times are modern as it is today.

Maybe this true that as in Clifford Geertz's book entitled Agricultural Involution: The Process of Indonesia Ecology Changes, it is stated that Madura and Java are "Outer Indonesia". ${ }^{21}$ From the point of view of ecological structure, Madura and Java are characterized by moor ecological structure and the outer islands, which are characterized by rice fields. The moor ecological structure is more concerned than rice fields because the plants depend on natural condition. This means that the plants depend more on the state of the rainfall. Thus, if the level of rainfall is low, the yield of moor is not optimal, and even causes famine (laep) when the dry season is prolonged.

19 A.R. Radcliffe -Brown, Structure and Function in Primitive Society (London: Routledge and Kegan Paul, 1952).

20 Zaini, "Local Public Figure" Direct Interview on 14 of July 2020.

21 Geertz divides Indonesia into two parts, namely Outer Indonesia and Inner Indonesia. Outer Indonesia includes Madura, Java, North West Java, Central, East, South Bali, and Lombok. Meanwhile, Inner Indonesia includesoutside Java and Southwest Java Clifford Geertz, Proses Perubahan Ekologi Indonesia (Jakarta: Bhatara Karya Aksara, 1983), 12. 
Unlike Radcliffe Brown, Malinowski sees anthropology in a different view. The difference seems very striking, Radcliffe Brown tries to see society in the frame of the structure as a whole, but Malonowski focuses more on his studies on each individual community. Malinowski sees and emphasizes the human aspect as a psycho-biological being who has a set of psychological and biological needs that need to be met.

Malinowski state that in order to meet the psycho-biological needs of individuals and maintain the continuity of the life of a social group, several minimum conditions must be met by the individual members of the social group. The minimum conditions consist of 7 basic needs, namely nutrition, reproduction, bodily comfort, safety, relaxation, movement, and growth. All activities carried out by individuals are in order to fulfill the 7 basic needs above. For more details, see the table below.

Synoptic Survey of Biological andd Derived Needs and Their Satisfaction in Culture 22

\begin{tabular}{|c|c|c|c|c|c|}
\hline $\begin{array}{l}\text { Basic } \\
\text { Needs } \\
\text { (Individual } \\
\text { ) }\end{array}$ & $\begin{array}{c}\text { Direct } \\
\text { Responses } \\
\text { Responses } \\
\text { (Organized, } \\
\text { i.e } \\
\text { Collective }\end{array}$ & $\begin{array}{c}\text { Instrumental } \\
\text { Needs }\end{array}$ & $\begin{array}{c}\text { Responses } \\
\text { to } \\
\text { Instrumenta } \\
1 \text { Needs }\end{array}$ & $\begin{array}{c}\text { Symbolic } \\
\text { integrative } \\
\text { needs }\end{array}$ & $\begin{array}{l}\text { Systems } \\
\text { of } \\
\text { Thought } \\
\text { and faith }\end{array}$ \\
\hline $\begin{array}{l}\text { Nutrition } \\
\text { (Metabolism) }\end{array}$ & Commisariat & $\begin{array}{l}\text { Renewal of } \\
\text { cultural } \\
\text { apparatuE }\end{array}$ & Economis & $\begin{array}{l}\text { Tranmissio } \\
\mathrm{n} \text { of } \\
\text { experience } \\
\text { by means of } \\
\text { precise, } \\
\text { consistent } \\
\text { principles }\end{array}$ & Knowledg \\
\hline $\begin{array}{r}\text { Reproductio } \\
\mathrm{n}\end{array}$ & $\begin{array}{l}\text { Marriage and } \\
\text { family }\end{array}$ & & & & \\
\hline $\begin{array}{l}\text { Bodily } \\
\text { contorts }\end{array}$ & $\begin{array}{l}\text { Domicile } \\
\text { and dress }\end{array}$ & $\begin{array}{l}\text { Charters of } \\
\text { behavior and } \\
\text { their sanctions }\end{array}$ & $\begin{array}{l}\text { Social } \\
\text { control }\end{array}$ & & \\
\hline Safety & $\begin{array}{l}\text { Protection } \\
\text { and }\end{array}$ & & & $\begin{array}{l}\text { Means of } \\
\text { intelectual. } \\
\text { emotional, }\end{array}$ & $\begin{array}{l}\text { Magic } \\
\text { religion }\end{array}$ \\
\hline
\end{tabular}

22 Bronislaw Malinowski, "The Group and the Individual in Functional Analysis," American Journal of Sociology, 1939, 44. 


\begin{tabular}{|c|c|c|c|c|c|}
\hline & & & & $\begin{array}{l}\text { and prag- } \\
\text { matic } \\
\text { control of } \\
\text { destiny and } \\
\text { chance }\end{array}$ & \\
\hline Relaxation & $\begin{array}{l}\text { Systems of } \\
\text { play and } \\
\text { repose }\end{array}$ & $\begin{array}{l}\text { Renewal of } \\
\text { personnel }\end{array}$ & Education & & \\
\hline Movement & $\begin{array}{l}\text { Set activities } \\
\text { and systems } \\
\text { of } \\
\text { communicati } \\
\text { on }\end{array}$ & & & & \\
\hline Growth & $\begin{array}{l}\text { Training and } \\
\text { apprenticeship }\end{array}$ & $\begin{array}{l}\text { Organization of } \\
\text { force and } \\
\text { compulsion }\end{array}$ & $\begin{array}{l}\text { Political } \\
\text { organization }\end{array}$ & $\begin{array}{l}\text { Communal } \\
\text { rhytim of } \\
\text { recreation. } \\
\text { exercise } \\
\text { and rest }\end{array}$ & \begin{tabular}{|l} 
Art sports \\
games \\
ceremonial
\end{tabular} \\
\hline
\end{tabular}

Based on the basic needs in the table above, binsabin and tongngebban are included in reproduction needs. Beside on it, $\mathrm{n}$ the book Sex and Repression in Savage Society (1927), Malinowski contrasted the animal instinctive basis of marriage and the production of offspring (biological inheritance) with the forms of social ties, the legal rules of marriage, and the beliefs and ceremonies that surround the marriage process. social heritage).23 In fulfilling sexual urges and emotions to produce offspring, human behavior is governed by a set of norms regarding marriage. and family. These norms are social heritage. This social heritage not only establishes obstacles and opportunities, advises on what is ideal and what is not, lays down values, but also influences the physiological attitude of men towards women through the legal system, ethics, religious principles, the concept of honor,holiness, and sin. This social heritage is imposed by society on each of its members. So, in this context, anthropology actually wants to study traditional practices in society, lest these

23 Bronislaw Malinowski, Sex and Repression in Savage Society (1927) (New York: Routledge, 2001). See also Tony Rudyansjah, Antropologi Agama (Jakarta: UI Press, 2012), 57. 
traditions actually perpetuate bad things, as in the Malinowski language, namely social heritage as described above.

\section{Binsabin and Tongngebban in Madura Engagement Based on Islamic Law}

After investigated in depth the binsabin and tongngebban traditions in Madurese customary engagement, in general there was permitted within Islamic law. In fact, the tradition that is carried out, from the beginning to the end of the procession contains positive values which fiqh iscalled 'Urf Shohih, it means good habits or traditions. 24

Binsabin and Tongngebban are actually forms of tradition which contain: First, formalizing an engagement contract between a man and a woman who has previously been bond (mogel) ${ }^{25}$ or was illegally engaged. ${ }^{26}$ In Islamic law, this contract is very important in conducting muamalat transactions. The contract can determine the future direction of something that is agreed upon, so that there is no dispute in the future.

Every Muslim depends on their contracts (Al-muslimuna 'ala syurutihim). This is what the Prophet (PBUH) taught during muamalat transactions with fellow Muslims. For muamalat problems, the Prophet entrusted to his people with his words, "Antuma'lamu bi umuriddun yakum (all of you know more about your world affairs)." Therefore, the issue of Madurese engagement can refer to what the Prophet (PBUH) had taught.

\footnotetext{
${ }^{24}$ In the discussion of mashadir al-Ahkam 'urf is one of the sources of law. However, the source of the law is not agreed upon (mukhtalaf), meaning that some scholars have different opinions as to whether 'urf is a source of Islamic law or not. There are two kinds of traditions ('urf) in society, namely: (1) good traditions ('Urf Shohih) which are good habits that are accepted both from a review of customary law and Islamic law. (2) bad traditions ('Urf Fasid) are habits that occur in society that cannot be accepted by sharia law'.

${ }^{25}$ M. Afnan Asrori A. Ma'ruf Chafidh, Tradisi Islami, Panduan Prosesi Kelahiran, Perkawinan, Kematian (Surabaya: Khalista, 2006), 109.See also Anwar Hafidzi and Norwahdah Rezky Amalia, "Marriage Problems Because of Disgrace (Study of Book Fiqh Islam Wa Adilâtuh and Kitâb Al-Nikâh," Al Ihkam: Jurnal Hukum Dan Pranata Sosial 13, no. 2 (2018): 275.

${ }^{26}$ Wahbah Zuhaili, Al-Figh Al-Islāmi Wa Adillatuh (Damaskus: Dar al Fikr, 2010), 24.
} 
A contract is a bond between the two parties, both concrete and abstract. The engagement contract, which is packed with Binsabin and Tonggebban processions, is a concrete contract. The two families have agreed to tie their sons and daughters in an engagement bond, and make a marriage promise within a specified time together.

A Muslim is obligatory to maintain and fulfill what has become the agreement if this contract has been agreed. According to Allah's command in al-Qur'an, “O, you who believe! Fulfill your covenants." 27 The contracts that must be maintained by both parties in the family are (1) maintaining the honor of each other by means of a mandate that he has been tied with an engagement rope; (2) jointly safeguard the good name of the family by not listening to slander raised by wicked people who want to destroy good relations between families; (3) under Islamic law, an engaged woman may no longer be married to another person unless it has been canceled. It is in accordance with the hadith of the Prophet Muhammad, narrated by Ibn Umar, namely:

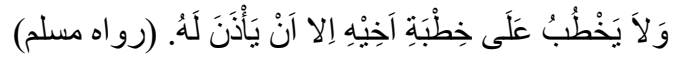

"The Prophet (PBUH) forbade people to propose to the woman who is being proposed by their brother until the person who first proposed gave permission to him." (Hadith Narrated by Muslim) 28

Second, in the Binsabin and Tongngebban processions, the two families alternately come to their respective houses within a predetermined time. This implies the existence of friendship, mutual affection in order to create emotional bonds among Muslims, and to increase the number of brothers and sisters who both want to live up to the Sunnah of the Prophet (PBUH), which is in the form of marriage. In Islamic law, it is highly recommended to keep in touch.

27 Al-Qur'an, Al-Maidah:1

${ }^{28}$ Abi Husein Muslim Ibn Hajjad al-Khushairi al-Nasaburi, Sahih Muslim, Juz I (Beirut: Dar al-Fikr, 1988), 647. See also in several Hadith: Muhammad Ibn Isma'il al-Amir San'ani, Subul Al Salam (Beirut: Dar al-Kutub al-'Ilmiyah, 1971), 111. Ibn Hajar Asqalani, Bulugh Al-Maram (Surabaya: Al Hidayah, n.d.), 201. Abd al-Rahman Muhammad Uthman, 'Ain Al-Ma'bud (Beirut: Dar al Fikr, n.d.), 96. 
People will be in the valley of humiliation if they do not connect with God and human relationships. The Prophet (PBUH) also indicated about the virtue of keeping in touch, which would extend our life and widen our sustenance. For this reason, the author has great enthusiasm in addressing the good traditions, in the form of Binsabin and Tongngebban in the Madurese engagement.

Third, the tradition is carrying goods (the items) as explained in the first problem statement. From the type of goods, there is no oddity. This means that the goods are not contrary to Islamic law. All of them are permitted halal items. The goods are also easy to find, and economically easy to buy, even by people in middle to lower economies.

The philosophical meaning that can be taken from this tradition is to give gifts to each other, or something that is of charity. Giving gifts to fellow Muslims is a religious doctrine and the Sunnah of the Prophet $(\mathrm{PBUH})$ because it can strengthen the bonds of brotherhood. Giving gifts can give unforgettable memories to the hearts of siblings. Therefore, it is very urgent to preserve this tradition, which actually contains religious values so that it does not just disappear, and it remains sustainable for future generations.

Today, many people are co-opted by the imitation of modern traditions, which are often not in accordance with the provisions of Islamic law. Not a few people practice engagement that deviates from the applicable provisions, including: First, during the engagement period, sometimes the man and the woman do not maintain social ethics. They think that the engagement relationship can eliminate the ajnabiyah law (the law that regulates the relationship between a man and a woman who is not a mahram). Before the marriage contract is carried out, it is forbidden to be together, sit, and date together without a mahram. Anything that can make slander between the two parties is forbidden.

Second, some Madurese people indicate an engagement by exchanging of rings. Usually, it is done by people who are economically capable. In this case, when viewed from the perspective of Islamic law, of course there is no violation whatsoever, and no one prohibits it. It is just that in social life there is an impression of luxury, especially when the engagement is packed with a very luxurious party. It is best to format the event as simply as possible; the most 
important thing is to fulfill the two laws, that is, legally based on Islamic law as well as the customary law.

Islamic law does not allow the ring exchange by engaged man and woman because their status is still ajnabiyah. If it is forced to do an engagement in which there is a ring exchange, then the best step is to embed the ring by the mahram. The man's party is performed by the prospective son-in-law or a representative, the woman's party is performed by the prospective daughter-in-law or a representative; in order to avoid sins. The two partners later become a sakinah, mawaddah, warahmah (happy, loving, and supportive) family. Only God knows.

\section{Conclusion}

This research concludes several things, First, anthropology perspective shows that structure and function of the Madurese are a representation of the strong traditions that have been rooted in the binsabin and tongngebban tradition communities. Anthropology also see that binsabin and tongngebban describe the fulfillment of individual psycho-biological needs and maintain the continuity of life of social groups. Anthropology also shows that strong the Madurese community is in upholding this tradition from generation to generation even though times have changed to modern times like today. Second, in the perspective of Islamic law, this tradition seeks to build three things, namely building a strong agreement between fellow Muslim families, secondly establishing friendship so as to create a strong emotional bond, thirdly sharing the joy shown by giving gifts or goods so as to increase the strength of brotherly bonds. in a religious way (engagement)

\section{Bibliography}

Abd al-Rahman Muhammad Uthman. 'Ain Al-Ma'bud. Beirut: Dar al Fikr, n.d.

Ahmad Warson Munawwir. Kamus Al-Munawwir. Surabaya: Pustaka Progressif, 1997.

Anwar Hafidzi and Norwahdah Rezky Amalia. "Marriage Problems Because of Disgrace (Study of Book Fiqh Islam Wa Adilâtuh and Kitâb Al-Nikâh." Al Ihkam: Jurnal Hukum Dan Pranata Sosial 13, no. 2 (2018). 
Asqalani, Ibn Hajar. Bulugh Al-Maram. Surabaya: Al Hidayah, n.d.

Asrori A. Ma'ruf Chafidh, M. Afnan. Tradisi Islami, Panduan Prosesi Kelahiran, Perkawinan, Kematian. Surabaya: Khalista, 2006.

Baal, J. Van. Sejarah Dan Pertumbuhan Teori Antropologi Budaya (Hingga Dekade 1970). I. Jakarta: PT. Gramedia, 1987.

Clifford Geertz. Proses Perubahan Ekologi Indonesia. Jakarta: Bhatara Karya Aksara, 1983.

H. Soeprijadi. “Local Public Figure.” 2020.

Malinowski, Bronislaw. Sex and Repression in Savage Society (1927). New York: Routledge, 2001.

- - . "The Group and the Individual in Functional Analysis." American Journal of Sociology, 1939.

Moleong, Lexy J. Metode Penelitian Kualitatif. Bandung: Rosda Karya, 2000.

Muhammad Ibn Isma'il al-Amir San'ani. Subul Al Salam. Beirut: Dar al-Kutub al-'Ilmiyah, 1971.

Pongsibone, H. Lebba Kadorre. Islam Dan Budaya Lokal; Kajian Antropologi Agama. Edited by M. Fatih Mansur. Kaukaba Dipantara. I. Yogyakarta: Kaukaba Dipantara, 1967.

Radcliffe -Brown, A.R. Structure and Function in Primitive Society. London: Routledge and Kegan Paul, 1952.

Suhaimi. "Praktik Khitbah Di Madura Perspektif Hukum Islam Dan Hukum Adat." Al Ihkam : Jurnal Hukum Dan Pranata Sosial IX, no. 2 (2014).

Tolib Setiady. Intisari Hukum Adat Indonesia. Bandung: Alfabeta, 2009.

Tony Rudyansjah. Antropologi Agama. Jakarta: UI Press, 2012.

Umi Supraptiningsih and Khoirul Bariyyah. "Marriage Settlement among Minority Moslem by Datok Imam Masjid in South Thailand." AL-IHKAM: Jurnal Hukum E Pranata Sosial 14 (2019).

Urip Santoso. "Local Public Figure." 2020.

Wahbah Zuhaili. Al-Figh Al-Islāmi Wa Adillatuh. Damaskus: Dar al Fikr, 2010.

Zaini. “Local Public Figure.” 2020. 